УДК 667.6:655.3.026.9:655.336

\title{
ВИБІР ОПТИМАЛЬНОГО ВАРІАНТУ ВИГОТОВЛЕННЯ НЕКОВЗЬКИХ СЕРВЕТОК-ПІДКЛАДОК
}

( К. А. Рябцева, магістрантка, Є. О. Полєв, магістрант, Л. Г. Вуєць, к.т.н., доцент, НТУУ «КПІ», Київ, Україна

Проведены исследования эффективности противоскользящих свойств салфеток-подкладок, используемых в транспорте, при разных вариантах их изготовления. Выбран вид бумаги, определены оптимальные значения толщины и площади покрытия салфеток виниловым лаком, обеспечивающие максимальное трение с материалами посуды.

The efficiency of anti-slip properties of the nonskid placemats, used in transport, was researched in different variations of their production. The kind of paper was chosen. The optimum value of thickness and area covered by vinyl lacquer which provided maximum friction with materials of tableware were proposed.

\section{Постановка проблеми}

Нековзькі серветки-підкладки являють собою вироби із білого або кольорового паперу, з можливим задруковуванням в одну або декілька фарб офсетним способом та вкриті шаром лаку на основі вінілових алкідно-акрилових сополімерів, нанесеним на одну або обидві поверхні трафаретним друком. Фарбове зображення надає серветці декоративної естетичності, а покриття вініловим лаком, збільшуючи силу тертя, упереджує ковзання посуду по серветці, коли та підкладена під нього.

Зазвичай серветки-підкладки використовують у літаках, потягах або інших видах транспорту, де харчування пасажирів передбачене під час руху, тому що вони зменшують ризик зісковзування посуду з таці чи столу. Нековзькі серветки-підкладки ви- робляються і застосовуються в різних країнах, однак в Україні виготовленням такого різновиду серветок зацікавились тільки у ТОВ «Інгул-Т». На його замовлення авторами статті були проведені дослідження з добору паперової основи, а також вивчено процес нанесення гальмівного лакового покриття з оформленням технічних умов на ці вироби.

\section{Мета роботи}

Метою роботи було дослідити зміну сили тертя спокою між поверхнями посуду та серветокпідкладок за різних варіантів нанесення вінілового лаку задля встановлення оптимальних гальмівних властивостей серветок, щоб розробити на їх основі технологію нанесення гальмівного шару і виготовлення виробів у цілому з урахуванням їх собівартості. 


\section{Результати проведених досліджень}

Під час руху транспортного засобу на посуд, що знаходиться на столі чи таці всередині рухомого складу, можуть діяти сили інерції прискорення чи гальмування, а також зміна положення площини столу відносно горизонталі. В цих випадках характеризувати гальмівні властивості серветок-підкладок належить визначенням сили статичного тертя або мінімального кута нахилу площини столу чи таці, що на них знаходиться посуд.

Взаємодія поверхонь серветки-підкладки та посуду, що знаходиться на ній, характеризується силою сухого тертя, яке спричинено нерівностями поверхонь, а також силами молекулярного зчеплення в місцях безпосереднього дотику. В цьому разі можна використовувати закон Амонтона, згідно з яким сила F тертя ковзання прямо пропорційна силі $\mathrm{N}$ нормального тиску між поверхнями ковзних тіл:

$$
F=f_{k} \cdot N \text {, }
$$

де $\mathrm{f}_{\mathrm{k}}$ - коефіцієнт тертя ковзання, залежний від властивостей матеріалу тіл. Тертя між взаємно нерухомими тілами виявляється у тому, що для відносного переміщення двох контактних тіл до одного із них потрібно прикласти зовнішню силу $\mathrm{F}>\mathrm{F}_{0}$, де $\mathrm{F}_{0}$ - гранична сила тертя спокою. Коефіцієнт $\mathrm{f}_{0}$, відповідний граничній силі спокою, завжди більший від коефіцієнта кінетичного тертя.

Замість коефіцієнта тертя $\mathrm{f}_{0}$ використовується кут $\mu$, що зв'язаний з $\mathrm{f}_{0}$ відношенням:

$$
\operatorname{tg} \mu=f_{0} .
$$

Кут дорівнює тому найменшому кутові нахилу площини до горизонталі, за якого покладене на ній тіло починає зісковзувати вниз під дією сили тяжіння [1].

Для визначення сили статичного тертя застосовувався метод тягового приводу, коли за допомогою пружинного динамометра фіксувалась сила, докладена в момент початку переміщення взірців матеріалів для виготовлення посуду (скло, пластмаса, кераміка, картон) по поверхнях виготовлених взірців нековзьких серветок-підкладок. Виходячи з отриманих результатів досліду розраховано статичний коефіцієнт тертя, який і $€$ найважливішою характеристикою нековзьких серветок:

$$
f_{0}=\frac{F_{0}}{P},
$$

де $\mathrm{F}_{0}$ - покази на шкалі динамометра в початку руху; P вага зразка матеріалу для виготовлення посуду, що використовувався у досліді.

Під час цього експерименту предмети зрушували з місця, докладаючи силу, що була направлена паралельно до горизонтальної поверхні. При застосуванні цього методу імітувалося переміщення посуду, що зазвичай спричинюване силами інерції у наземному транспорті, потязі або автобусі. У літаках або на водному транспорті рух предметів по горизонтальній поверхні спричиняється саме їі нахилом. Для більшої точності 


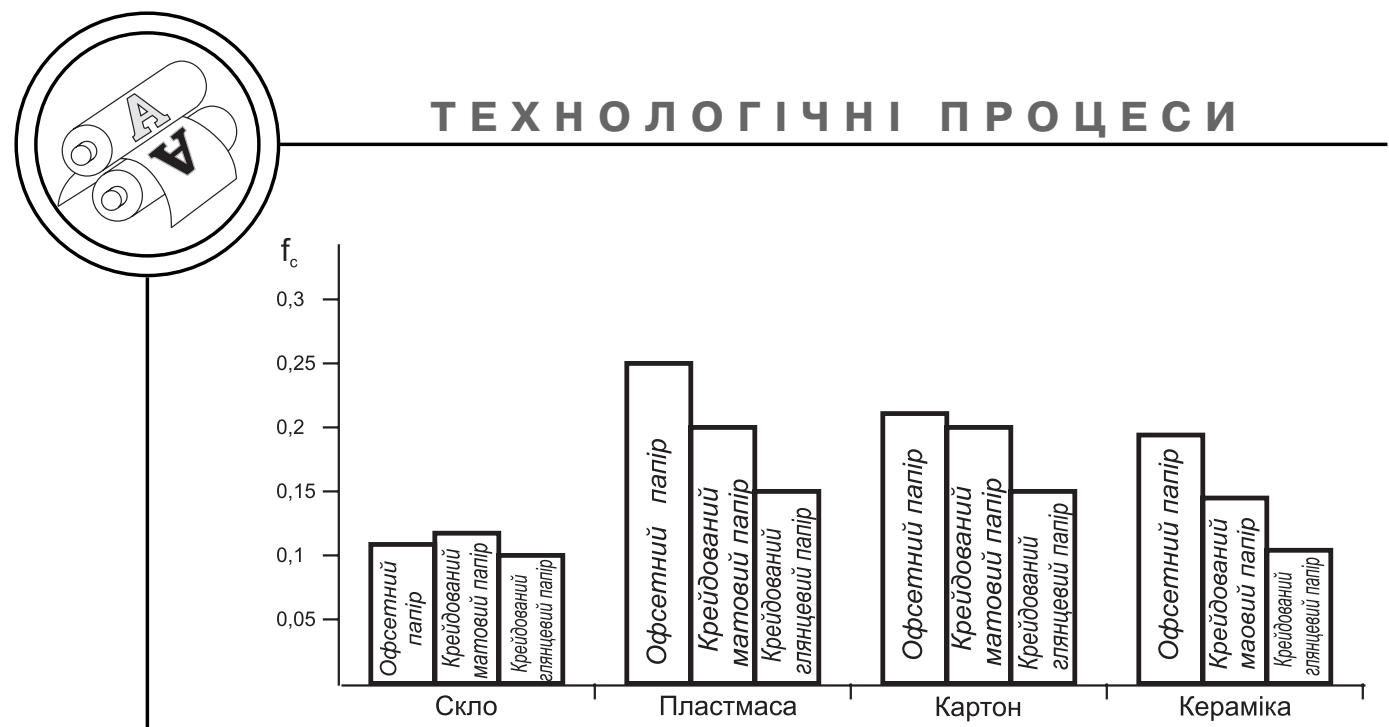

Рис. 1. Статичний коефіцієнт тертя для різних видів паперу

визначення статичного коефіцієнту тертя було проведено іншу серію експериментів з використанням лабораторного стенду, де фіксувався граничний кут нахилу площини із взірцями нековзьких серветок, при якому зразки матеріалів посуду починали зісковзувати. За кінцевий результат коефіцієнта тертя (2) приймалося середнє значення за результатами двох описаних вище експериментів.

Дослідження зразків паперу показали найбільші коефіцієнти статичного тертя з матеріалами посуду у офсетних його різновидів (рис. 1), що пояснюється більш шорсткою їх поверхнею, на відміну від крейдованих видів паперу.

Офсетний папір повністю задовольняє вимоги до основи серветки, зважаючи на його помірну вартість та на отримані показники коефіцієнтів тертя. Нанесений офсетним способом друк істотно не змінює значення цих коефіцієнтів.

Площа покриття серветок гальмівним лаком при трафаретному способі його нанесення може змінюватися за рахунок зміни діаметру нанесених цяток при їх постійній кількості на розмірній одиниці площі або ж зміною кількості цяток на одиниці площі при їх однаковому діаметрі. Для порівняння цих двох варіантів виготовлення серветок коефіцієнт тертя визначався для двох типів зразків. Перші характеризувалися кількістю цяток на квадратний сантиметр $(6,8$, $12,25,36)$, що мали однаковий діаметр 0,8 мм. Друга група зразків відрізнялась за діаметром точок гальмівного шару $(0,7 ; 0,8 ; 1 ; 1,5 ; 2,5$ мм), які були розміщенні по 8 цятках/см². Відносна площа покриття зразків серветок гальмівним лаком розраховувалась за формулою:

$$
\begin{aligned}
& \mathrm{S}_{\text {відн }}=\mathrm{S}_{\text {точки }} \cdot \mathrm{n} \cdot 100 \%= \\
& =\frac{\pi \cdot \mathrm{D}^{2} \cdot \mathrm{n}}{4} \cdot 100 \%,
\end{aligned}
$$

де D - діаметр цятки; $\mathrm{n}$ кількість цяток на см².

Аналізуючи залежності коефіцієнта тертя від покритої лаком площі для двох варіантів виконання серветок (рис. 2, 3), можна зробити висновок, 


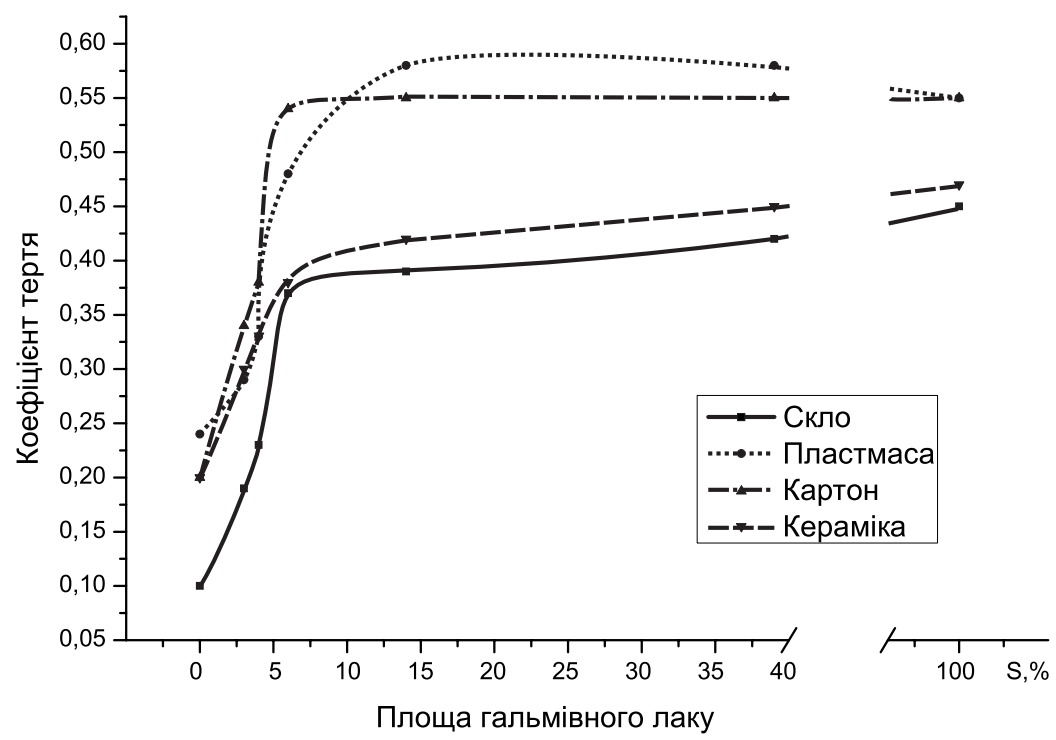

Рис. 2. Залежність статичного коефіцієнту тертя від зміни діаметру цяток гальмівного вінілового лаку

що збільшення кількості цяток $€$ більш ефективним способом підвищення коефіцієнту тертя гальмівного лаку на серветці. Для картону та пластмаси, на- ром 0,8 мм на квадратному сан-

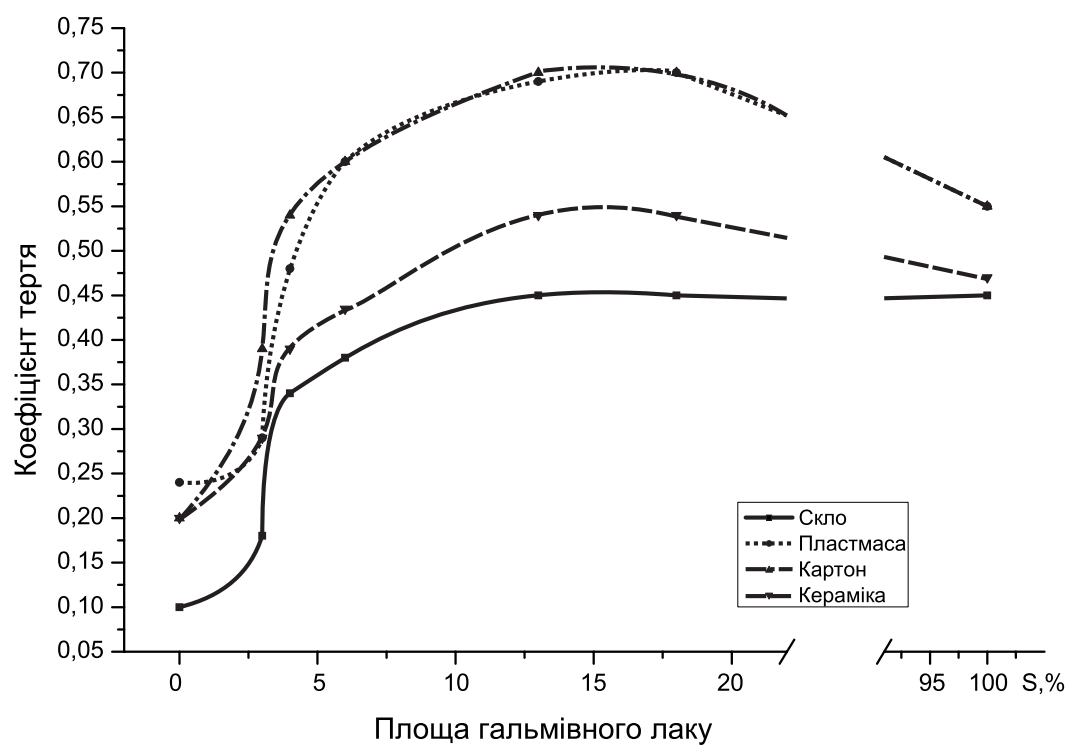

Рис. 3. Залежність статичного коефіцієнту тертя від зміни діаметру цяток гальмівного вінілового лаку 


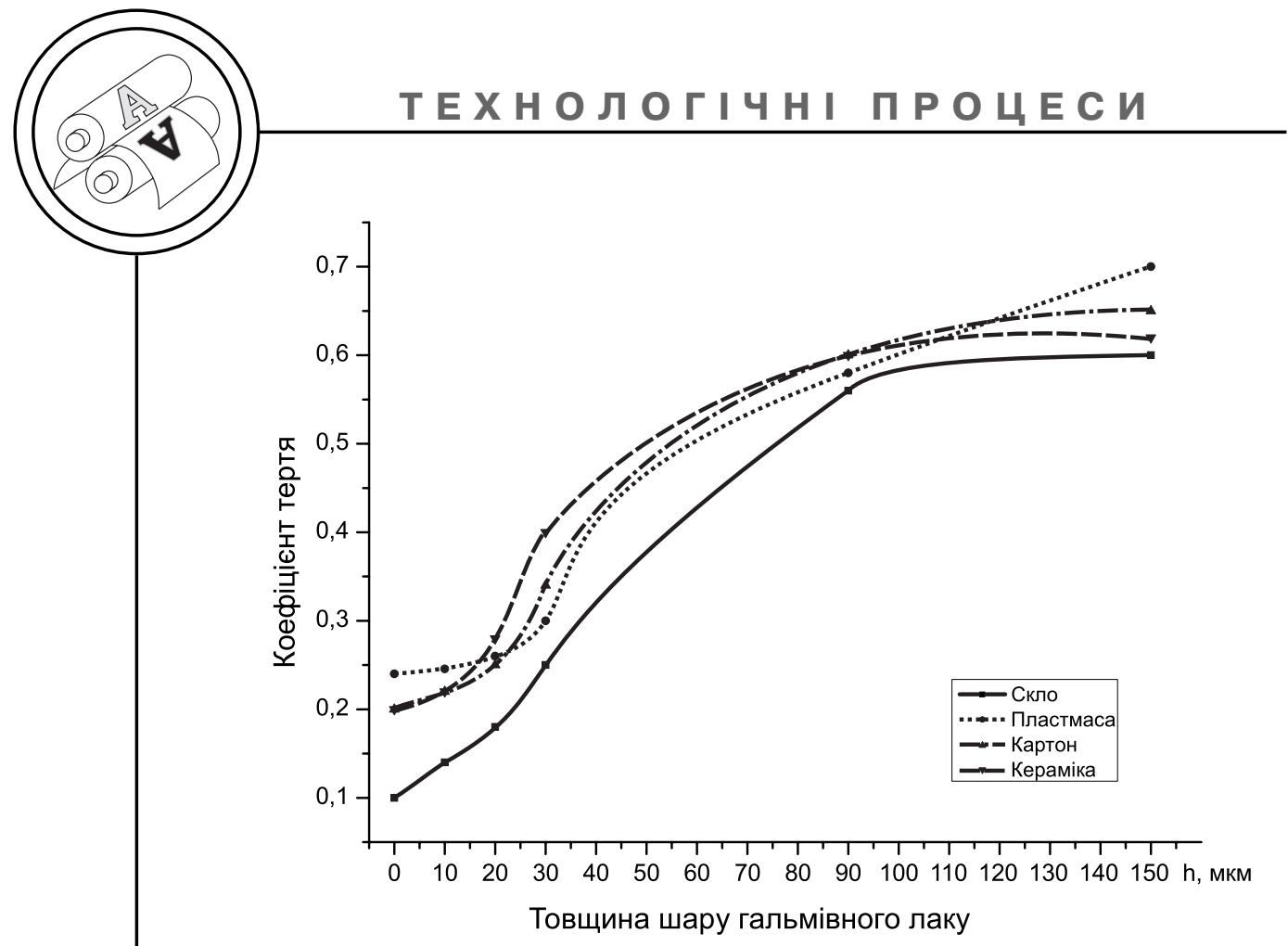

Рис. 4. Залежність статичного коефіцієнту тертя від зміни товщини шару гальмівного вінілового лаку

тиметрі. При такій площі покриття, отриманій за рахунок збільшення діаметру цяток, значення коефіцієнту тертя 0,7 не досягалось.

Для визначення залежності коефіцієнта тертя від товщини нанесеного шару гальмівного лаку використовувались зразки з шаром вінілового лаку товщиною від 10 до 150 мкм (рис. 4).

Оскільки шар менше 10 мкм майже не змінює властивостей виробу, а більше 60 мкм використовувати недоцільно, зважаючи на економічність виготовлення, то на практиці варто застосовувати покриття в діапазоні від 10 до 60 мкм.

Зважаючи на всі залежності за даними експериментів, найефективніший варіант виконання нековзької серветки-підкладки - це серветка, вироблена на офсетному папері 3 гальмівним шаром не більш як у 60 мкм, нанесеним у вигляді регулярних цяток діаметром 0,8 мм та кількістю 25 цяток/см². Користуючись отриманими даними, можна побудувати модель, що включатиме $\mathrm{f}_{0}(\mathrm{~S})$ та $\mathrm{f}_{0}(\mathrm{~h})$ - по суті, вона відображатиме залежність ефективності нековзької серветки від витрати лаку для гальмівного шару.

Результати проведених досліджень взяті за основу в технічних умовах на нековзькі серветки-підкладки [2].

\section{Висновки}

Проведено дослідження показників ефективності гальмівних властивостей нековзьких 
серветок-підкладок при різних характеристиках нанесеного шару вінілового лаку.

Визначено вид паперу та оптимальний варіант нанесення гальмівного шару вінілового ла- ку трафаретним друком, що забезпечило максимальне тертя поверхонь серветок-підкладок та столового посуду.

Розроблено технічні умови на нековзькі серветки-підкладки.

1. Яворский Б. М. Справочник по физике для инженеров и студентов вузов / Б. М. Яворский, А. А. Детлаф. - М. : Наука, 1979. - 942 с. 2. тУ у 21.2-36239984-001:2010 Вироби з паперу господарсько-побутового призначення.

$$
\begin{array}{r}
\text { Рецензент - В. П. Шерстюк, д.х.н., } \\
\text { професор, НТУУ «КП|» }
\end{array}
$$

